Erratum

\title{
Erratum: Villegas-Ch, W., et al. A Business Intelligence Framework for Analyzing Educational Data. Sustainability 2020, 12, 5745
}

\author{
William Villegas-Ch ${ }^{1, *(\mathbb{D})}$, Xavier Palacios-Pacheco ${ }^{2}$ and Sergio Luján-Mora ${ }^{3}$ (D) \\ 1 Escuela de Ingeniería en Tecnologías de la Información, FICA, Universidad de Las Américas, \\ Quito 170125, Ecuador \\ 2 Departamento de Sistemas, Universidad Internacional del Ecuador, Quito 170411, Ecuador; \\ xpalacio@uide.edu.ec \\ 3 Departamento de Lenguajes y Sistemas Informáticos, Universidad de Alicante, 03690 Alicante, Spain; \\ sergio.lujan@ua.es \\ * Correspondence: william.villegas@udla.edu.ec; Tel.: +593-098-136-4068
}

check for updates

Citation: Villegas-Ch, W.; Palacios-Pacheco, X.; Luján-Mora, S. Erratum: Villegas-Ch, W., et al. A Business Intelligence Framework for Analyzing Educational Data. Sustainability 2020, 12, 5745. Sustainability 2021, 13, 3105. https:// doi.org/10.3390/su13063105

Received: 26 January 2021 Accepted: 4 February 2021 Published: 12 March 2021

Publisher's Note: MDPI stays neutral with regard to jurisdictional claims in published maps and institutional affiliations.

Copyright: (c) 2021 by the authors. Licensee MDPI, Basel, Switzerland. This article is an open access article distributed under the terms and conditions of the Creative Commons Attribution (CC BY) license (https:// creativecommons.org/licenses/by/ $4.0 /)$.
The authors would like to make the following corrections to the published paper [1]. The changes are as follows:

(1) Replacing affiliation 1:

School of Engineering in Information Technology, FICA, University of the Americas with

Escuela de Ingeniería en Tecnologías de la Información, FICA, Universidad de Las Américas (2) Replacing affiliation 2:

Department of Systems, International University of Ecuador with

Departamento de Sistemas, Universidad Internacional del Ecuador

(3) Replacing affiliation 3:

Department of Software and Computing Systems, University of Alicante with

Departamento de Lenguajes y Sistemas Informáticos, Universidad de Alicante

\section{Reference}

1. Villegas-Ch, W.; Palacios-Pacheco, X.; Luján-Mora, S. A Business Intelligence Framework for Analyzing Educational Data. Sustainability 2020, 12, 5745. [CrossRef] 